\section{Aging and cancer resistance in lymphoid progenitors are linked processes conferred by $16^{\text {Ink4a }}$ and Arf}

\author{
Robert A.J. Signer, ${ }^{1}$ \\ Encarnacion Montecino-Rodriguez, ${ }^{1}$ \\ Owen N. Witte, ${ }^{2,3,4}$ and Kenneth Dorshkind ${ }^{1,5}$ \\ ${ }^{1}$ Department of Pathology and Laboratory Medicine, \\ University of California at Los Angeles, Los Angeles, \\ California 90095, USA; ${ }^{2}$ Department of Microbiology, \\ Immunology, and Molecular Genetics, University of \\ California at Los Angeles, Los Angeles, California 90095, \\ USA; ${ }^{3}$ Department of Molecular and Medical Pharmacology, \\ University of California at Los Angeles, Los Angeles, \\ California 90095, USA ${ }^{4}$ The Howard Hughes Medical \\ Institute, David Geffen School of Medicine, University of \\ California at Los Angeles, Los Angeles, California 90095, USA
}

Lymphoid progenitors exhibit severe growth defects during aging while myelopoiesis is relatively unperturbed. These effects are due in part to the preferential expression of $\mathbf{p} 16^{\text {Ink4a }}$ and Arf in aged lymphoid progenitors. Their increased expression contributes to reduced growth and survival of lymphoid progenitors and makes them refractory to malignant transformation. Downregulation of $\mathrm{p}^{16^{\text {Ink4a }}}$ and Arf in aged lymphoid progenitors reverted the senescent phenotype and restored susceptibility to transformation. These data provide a molecular explanation for the preferential effects of aging on lymphopoiesis, suggest that inhibiting $\mathrm{p}^{16^{\text {Ink4a }}}$ and Arf expression can rejuvenate B lymphopoiesis, and link aging and cancer resistance.

Supplemental material is available at http://www.genesdev.org.

Received July 15, 2008; revised version accepted September $25,2008$.

Within the hematopoietic system, the lymphoid lineage is particularly sensitive to the effects of aging (Min et al. 2005; Signer et al. 2007a). B lineage progenitors, including common lymphoid progenitors (CLPs) (Kondo et al. 1997), pre-pro-B, pro-B, and pre-B cells (Hardy et al. 1991), all undergo significant declines in frequency and number (Stephan et al. 1996; Van der Put et al. 2004) owing to severe deficits in proliferation and survival (Miller and Allman 2003; Min et al. 2006). This is in contrast to myeloid progenitors (Akashi et al. 2000), which increase in number in aged mice and exhibit only minor attenuation of their proliferative potential (Rossi et al. 2005; Min et al. 2006; Signer et al. 2007b). The molecular basis for these nonuniform effects of aging is unknown.

[Keywords: Aging; hematopoiesisl; cancer; p16 ${ }^{\text {Ink4a }}$; Arf; Bmi-1] ${ }^{5}$ Corresponding author.

E-MAIL kdorshki@mednet.ucla.edu; FAX (310) 206-9391.

Article is online at http://www.genesdev.org/cgi/doi/10.1101/gad.1715808.
Recent findings from our laboratory demonstrated that in addition to declines in growth and survival, aged lymphoid progenitors have reduced leukemogenic potential (Signer et al. 2007b). When pro-B and pre-B (pro-/pre-B) cells were isolated from the bone marrow (BM) of young mice and transformed with BCR-ABL, which is associated with a subset of pre-B acute lymphoblastic leukemia in addition to chronic myeloid leukemia (Wong and Witte 2004), they underwent significant expansion in vitro and generated lymphoproliferative disease following transplantation in vivo. In contrast, B-cell progenitors isolated from the BM of old mice exhibited minimal expansion in vitro and did not generate leukemia in vivo. These findings are consistent with the suggestion that, at least in the hematopoietic system, aging and cancer resistance are linked processes (Kim and Sharpless 2006; Sharpless and DePinho 2007). In this case, the genetic mechanisms that contribute to declines in lymphopoiesis with age should also confer resistance to leukemogenesis.

A major molecular signature of aging in most rodent and human tissues is increased expression of $\mathrm{p}^{\text {Ink }} 6^{\text {In }}$ and Arf (Zindy et al. 1997; Nielsen et al. 1999; Krishnamurthy et al. 2004), both products of the Cdkn2a tumor suppressor locus. p16 $6^{\text {Ink4a }}$ and Arf are potent cell cycle inhibitors that regulate the $\mathrm{Rb}$ and $\mathrm{p} 53$ pathways, respectively (Sherr and McCormick 2002). Increased expression of $\mathrm{p} 16^{\text {Ink4a }}$ in particular has been implicated in the decline of stem and progenitor cell function in various tissues (Janzen et al. 2006; Krishnamurthy et al. 2006; Molofsky et al. 2006). The increased expression of p16 $6^{\text {Ink4a }}$ and Arf in aging tissues is thought to confer protection against cancer by inducing senescence in response to the accumulation of oncogenic stressors-including DNA damage, reactive oxidative species, and telomere attrition - that accumulate over the lifetime of the individual (Kim and Sharpless 2006; Rossi et al. 2008). In view of their proposed role as mediators of cellular senescence and tumor suppression, we examined the possibility that $\mathrm{p} 16^{\text {Ink4a }}$ and Arf are responsible for the dichotomous effects of aging in the hematopoietic system.

\section{Results and Discussion}

The expression levels of $\mathrm{p} 16^{\text {Ink4a }}$ and Arf increase in BM with age (Krishnamurthy et al. 2004), but a detailed lineage analysis has not been reported. Therefore, their expression was assessed by quantitative PCR (qPCR) in hematopoietic progenitors isolated from the BM of young (4-6 wk) and old (78-90 wk) mice (Fig. 1A-F). Despite being increased in hematopoietic stem cells (HSCs) (Spangrude et al. 1988; Yilmaz et al. 2006) with age (Supplemental Fig. S1; Janzen et al. 2006), the expression patterns of $\mathrm{p}^{\text {Ink4a }}$ and Arf in B lineage cells were distinct from those in myeloid progenitors. Expression of p16 ${ }^{\text {Ink4a }}$ was significantly increased in all stages of B lymphopoiesis in old mice, particularly in pro-B and pre-B cells, which exhibited a 17-fold elevation (Fig. 1G). In stark contrast, aged myeloid progenitors failed to express detectable levels of p16 $6^{\text {Ink4a }}$ (Fig. 1G). The distinct pattern of expression was also the case for Arf, as its relative expression was moderately increased in all B lineage cell fractions while myeloid progenitors did not ex- 

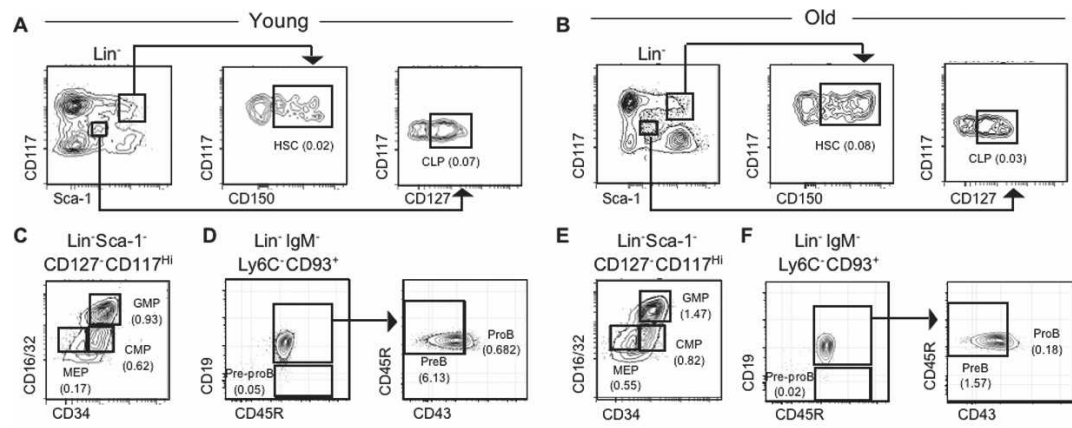

E

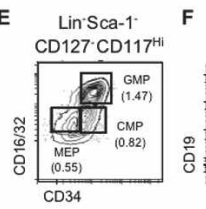

F $\quad \operatorname{Lin}^{\circ} \lg M$

$\mathrm{Ly}^{\circ} \mathrm{C}^{\cdot} \mathrm{CD}^{-} 3^{+}$
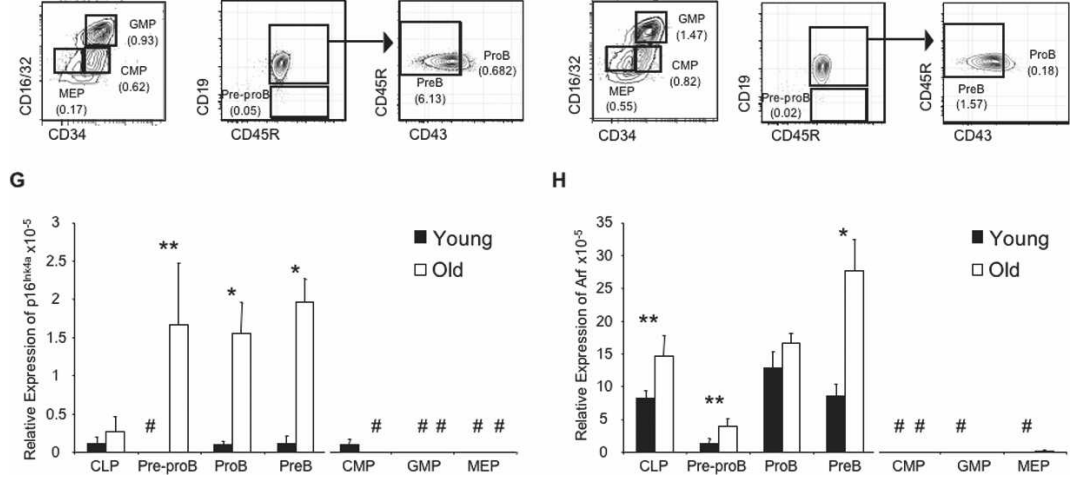

Figure 1. $\mathrm{p} 16^{\text {Ink4a }}$ and Arf are preferentially expressed in aging B lineage progenitors. $(A-F)$ Representative immunostaining profiles used to purify HSCs and CLPs $(A, B)$; common myeloid progenitors (CMPs), granulocyte macrophage progenitors (GMPs), and megakaryocyte erythroid progenitors (MEPs) $(C, E)$; and pre-pro-B cells, pro-B cells, and pre-B cells $(D, F)$ from mice. The frequency of each population is indicated in parentheses. The frequencies of lymphoid progenitors are decreased and the frequencies of HSC and myeloid progenitors are increased in the BM of old mice. Expression of p16 Ink4a $(G)$ and Arf $(H)$ relative to $\beta$-Actin in the indicated young and old purified populations was assessed by qPCR. $P$ values for each population are based on comparison of old versus young cells. $\left(^{\star}\right) P<0.005$; $\left(^{\star \star}\right)$ $P<0.1$; (\#) expression below level of detection. Each population was purified in two independent experiments from BM cell suspensions pooled from four to six young or old C57BL/6 mice, respectively. Reactions for each population were run a total of eight times.

press detectable levels (Fig. $1 \mathrm{H}$ ). Preliminary data indicate that $16^{\text {Ink4a }}$ expression also increases in early thymocyte progenitors (ETP) (E. Montecino, R. Signer, and K. Dorshkind, unpubl.). These data suggest that $\mathrm{p} 16^{\text {Ink } 4 a}$ and Arf are reliable biomarkers of physiological aging in the lymphoid lineage.

Although p16 ${ }^{\text {Ink4a }}$ and Arf are gatekeepers of cell cycle progression and apoptosis (Sherr 2001), they may have distinct tissue-related effects. For example, in aging skeletal muscle of hypomorphic BubR1 mice, $16^{\text {Ink4a }}$ is a mediator and Arf an attenuator of senescence (Baker et al. 2008). In order to define their role in the age-related decline of B lymphopoiesis, pro-/pre-B cells were isolated from the BM of young and old mice, transduced with retroviruses encoding either $\mathrm{p} 16^{\text {Ink } 4 \mathrm{a}}$, Arf, or GFP, and grown in vitro for $5 \mathrm{~d}$ (Fig. 2A). Young pro-/pre-B cells transduced with $\mathrm{p} 16^{\text {Ink4a }}$ exhibited a significant reduction in cell production (Fig. 2B) marked by a decline in the frequency of proliferating $\mathrm{Ki}^{+} 7^{+}$cells (data not shown) and a sharp increase in the frequency of AnnexinV $V^{+}$apoptotic cells compared with GFP transduced controls (Fig. 2C,D). Overexpression of Arf caused a similar but more severe phenotype, as massive cell loss was already evident at day 2 (Supplemental Fig. S2) and was associated with a much larger increase in the frequency of apoptotic cells at day 5 (Fig. 2C). Overexpression of $\mathrm{p} 16^{\text {Ink } 4 \mathrm{a}}$ or Arf in old pro-/pre-B cells resulted in complete cell loss by day 5 (data not shown). These data indicate that ectopic expression of $\mathrm{p} 16^{\operatorname{Ink} 4 a}$ and Arf confers decreased growth and survival on young pro-/pre-B cells that mimic the effects of aging. Therefore, it is likely that $\mathrm{p} 16^{\text {Ink4a }}$ and Arf, whose expression is dramati- cally up-regulated with age, are both biomarkers and effectors of B lineage senescence.

A loss of expression of Bmi-1 (in Bmi$1^{-/-}$mice), a potent repressor of both p16 ${ }^{\text {Ink4a }}$ and Arf expression, results in a severe decline in B lymphopoiesis (Jacobs et al. 1999; Park et al. 2003). We thus examined if expression of Bmi-1 was down-regulated in aging $\mathrm{B}$ lineage cells. Consistent with previous studies, we did not observe a significant change in Bmi-1 expression in unfractionated BM or HSCs from old mice (Fig. 3A; Janzen et al. 2006). However, there was a threefold reduction in Bmi-1 expression in old pro-B cells and a 15 -fold reduction in old pre-B cells relative to their young counterparts (Fig. 3A). Interestingly, we saw no such decline in $\operatorname{IgM}^{+}$B cells (Fig. 3A), despite the fact that they similarly up-regulate $\mathrm{p} 16^{\text {Ink4a }}$ and Arf (Supplemental Fig. S1). In addition, when we examined the expression of Id1 and Ets1, two other regulators of $\mathrm{p} 16^{\text {Ink } 4 \mathrm{a}}$ expression (Ohtani et al. 2001), we similarly found distinct changes in expression patterns between HSCs, B cell progenitors, and mature B cells. The expression of Id1, a repressor of p16 $6^{\text {Ink } 4 a}$, was significantly reduced in aged pre-B cells but not in HSCs or $\operatorname{IgM}^{+}$cells (Fig. 3B) while Ets 1 , an activator of p16 $16^{\text {Ink4a }}$, was upregulated in aged $\mathrm{IgM}^{+}$cells but not in HSCs, pro-B, or pre-B cells (Fig. 3C). These observations suggest that $\mathrm{p} 16^{\text {Ink4a }}$ and Arf expression may be regulated by different mechanisms in stem cells, committed progenitors and their mature progeny.

We next examined how loss of $\mathrm{p} 16^{\text {Ink4a }}$ and Arf expression affects $B$ lineage aging. Mice with a targeted deletion of p16 ${ }^{\text {Ink4a }}$ (Sharpless et al. 2001), Arf (Kamijo et al. 1997), or the entire Cdkn2a locus (Serrano et al. 1996) have been generated, but the latter two strains fail to reach old age and all animals develop spontaneous hematopoietic/nonhematopoietic tumors that could directly/indirectly affect $\mathrm{B}$ lymphopoiesis. Therefore, we manipulated the expression of $\mathrm{p} 16^{\text {Ink4a }}$ and/or Arf in cells from aged, wild-type mice with Bmi-1- or shRNAmediated knockdown. This approach also allowed us to determine the degree to which age-related declines in $\mathrm{B}$ lymphopoiesis could be reversed.

Accordingly, equivalent numbers of pro-/pre-B cells isolated from the BM of young and old mice were transduced with retroviruses encoding either Bmi-1 or GFP and grown in vitro for 10-15 d. Ectopic Bmi-1 expression in old pro-/pre-B cells completely reversed their proliferative and survival defects, as they expanded even more than young GFP transduced pro-/pre-B cells (Fig. 4A). This reversal in phenotype correlated with a concomitant decline in p16 $6^{\text {Ink4a }}$ and Arf expression (Fig. 4B), an increased frequency of $\mathrm{Ki}^{+} 7^{+}$cells, and a decreased frequency of Annexin $\mathrm{V}^{+}$cells relative to their GFP transduced counterparts (Fig. 4C,D). The growth potential of old pro-/pre-B cells was also improved following shRNAmediated knockdown of p16 $6^{\text {Ink } 4 a}$ (Supplemental Fig. S3), suggesting that the actions of Bmi-1 were mediated at 
A

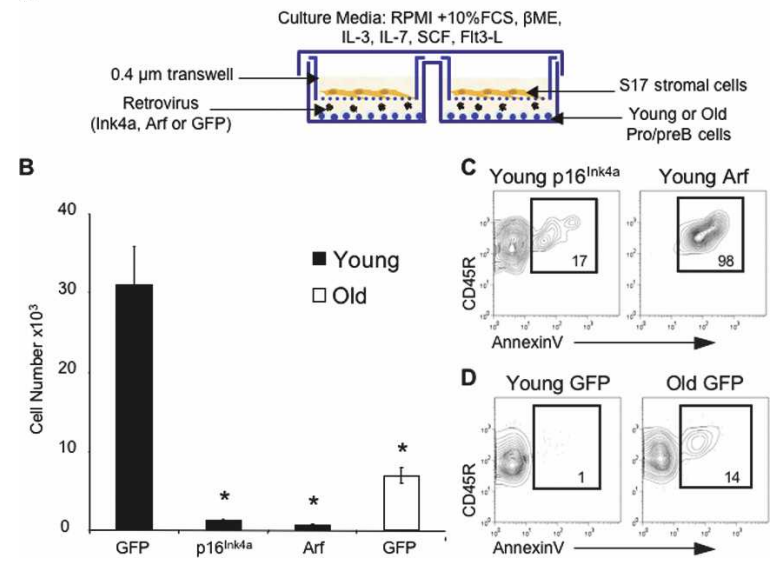

Figure 2. Ectopic expression of $\mathrm{p} 16^{\text {Ink4a }}$ and Arf mimic the effects of aging in young B lineage cells. (A) Experimental system used for transduction and growth of pro-/pre-B cells. $(B)$ Number of cells harvested from cultures $5 \mathrm{~d}$ following transduction of purified $\mathrm{Lin}^{-} \mathrm{Ly} 6 \mathrm{C}^{-} \mathrm{IgM}^{-} \mathrm{CD} 93^{+} \mathrm{CD} 45 \mathrm{R}^{+} \mathrm{CD} 19^{+}$pro-/pre-B cells with retroviruses encoding either GFP, $\mathrm{p} 16^{\text {Ink4a }}$ or Arf. $P$ values are based on comparisons between each population and the young GFP transduced cells. $\left({ }^{\star}\right) P<0.05$. The data are based on transduced cells only. $(C, D)$ Ectopic expression of $\mathrm{p} 16^{\text {Ink4a }}(C$, top left panel) or Arf $(C$, top right panel) results in an increase in the frequency of apoptotic Annexin $^{+}$cells in young pro-/pre-B cells when compared with young and old GFP transduced pro-/pre-B cells $(D)$. Plots shown are gated on live $\mathrm{GFP}^{+}$cells.

least in part by suppressing the $C d k n 2 a$ locus. Notably, the Bmi-1 transduced cells remained fully competent to differentiate into $\mathrm{IgM}^{+}$lymphocytes (Fig. 4E). Furthermore, overexpression of Bmi-1 in pro-/pre-B cells did not confer long-term self-renewal or cause malignant transformation in vivo, as transduced pro-/pre-B cells, which normally mediate only short-term reconstitution in vivo, were not detectable in the BM or spleen at $2 \mathrm{wk}$ $(n=16)$ post-transplantation, and recipients followed for up to 8 mo showed no signs of disease $(n=10)$ (data not shown).

It has been shown that transgenic mice with moderately increased expression of $\mathrm{p} 16^{\text {Ink4a }}$ and Arf have heightened resistance to malignant transformation (Matheu et al. 2004). However, whether increased expression of $\mathrm{p} 16^{\text {Ink4a }}$ and Arf in the context of normal aging enhances resistance to cancer has not been examined. To test this, pro-/pre-B cells were isolated from young and old mice, transduced with retroviruses encoding BCR-ABL-IRES-YFP and/or Bmi-1-IRES-GFP, sorted according to their expression of YFP and/or GFP, and transplanted into $\mathrm{Rag}^{-1-}$ recipients. Consistent with our previous findings (Signer et al. 2007b), 25\% of recipients of BCR-ABL transduced young pro-/pre-B cells developed B lymphoid leukemia. However, none of the recipients of BCR-ABL transduced old cells exhibited any signs of disease (Fig. 5A). In contrast, $100 \%$ of recipients of old and young pro-/pre-B cells cotransduced with Bmi-1 and BCR-ABL rapidly developed B lymphoid leukemia (Fig. 5A), marked by splenomegaly, lymphadenopathy, and infiltration of various tissues (data not shown). Leukemias derived from young or old BCR-ABL/Bmi-1 cotransduced cells were indistinguishable both phenotypically and morphologically (Fig. 5B-I; Supplemental Fig. S4). These data suggest that suppression of the Cakn2a locus by ectopic expression of Bmi-1 allows old
pro-/pre-B cells, which are normally refractory to transformation by BCR-ABL, to become leukemogenic.

This study provides a molecular explanation for the dichotomous effects of aging in the B lymphoid and myeloid lineages and demonstrates that aging and cancer resistance are linked processes in the hematopoietic system. Many oncogenes, including BCR-ABL, induce expression of Arf (Williams et al. 2006) or p16 ${ }^{\text {Ink4a }}$ (Serrano et al. 1997), which subsequently mediate tumor suppression by effecting senescence or apoptosis (Sachs et al. 2004). Thus, the marked resistance of aged B-cell progenitors to leukemogenesis is likely due to their high basal expression of $\mathrm{p} 16^{\text {Ink4a }}$ and Arf, which would precipitate the induction of oncogene induced senescence. The supposition that $\mathrm{p} 16^{\text {Ink4a }}$ and Arf play a critical role in limiting the development of lymphoid leukemias during aging is in agreement with studies demonstrating that $\mathrm{B}$ cell malignancies are among the most common type of spontaneous tumors that develop in Ink4a/Arf ${ }^{-/-}$ mice (Serrano et al. 1996), and that Arf gene loss synergizes with BCR-ABL to potentiate B lymphoid leukemia (Williams et al. 2006).

Interestingly, lymphoid, but not myeloid, leukemias often present with deletions of the Cdkn2a locus (Mullighan et al. 2008). Because p16 $6^{\text {Ink4a }}$ and Arf are not expressed in the myeloid lineage, their deletion would thus confer no growth benefit to myeloid tumors. However,

A



B

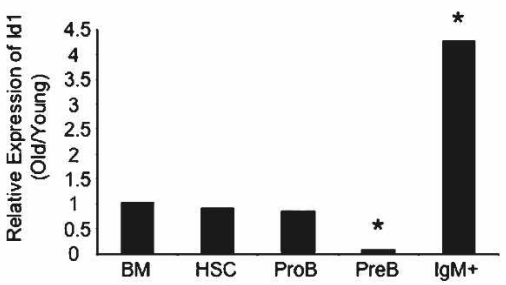

C

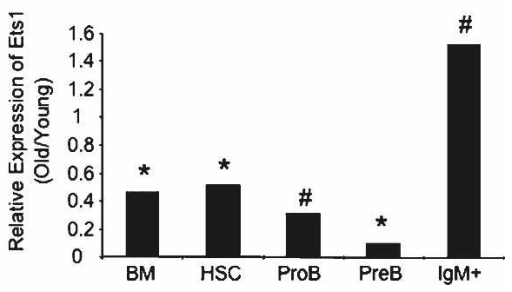

Figure 3. Bmi-1, Id1, and Ets 1 exhibit differential, age-related patterns of expression in hematopoietic progenitors. Changes in expression of Bmi-1 $(A), \operatorname{Id} 1(B)$, and Ets1 $(C)$ relative to $\beta$-Actin in the indicated populations with age. Values are reported as the mean ratio of expression in old versus young cells. $P$ values are based on comparison of expression levels in old versus young cells within each population $\left({ }^{\star} P<0.05 ; \# P<0.0006\right)$. Samples were the same as used in Figure 1 and Supplemental Figure S1. 
A

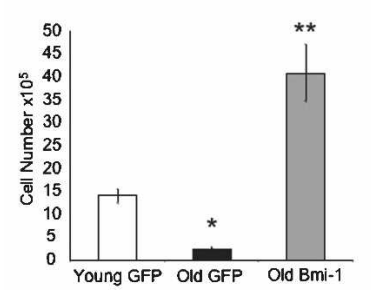

B

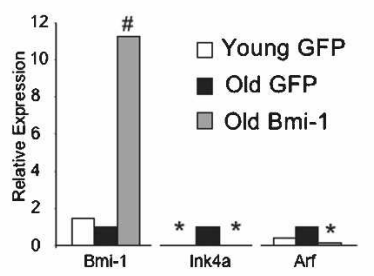

c

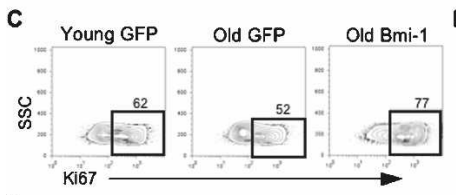

D
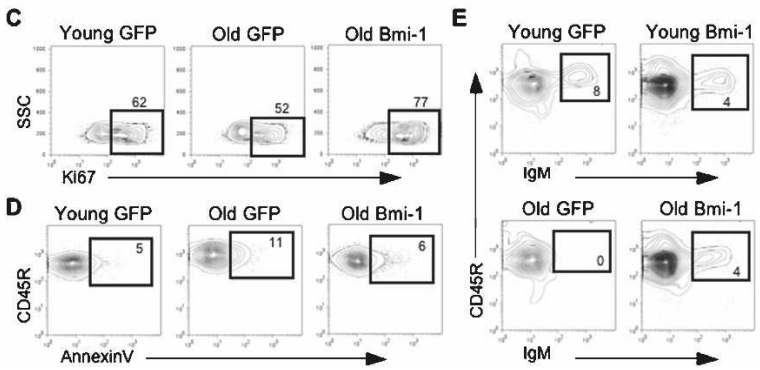

Figure 4. Restoring expression of Bmi-1 rescues proliferative defects in aged B lineage cells. $(A)$ Number of cells harvested from cultures $15 \mathrm{~d}$ following transduction of purified $\mathrm{Lin}^{-} \mathrm{Ly} 6 \mathrm{C}^{-} \mathrm{IgM}^{-} \mathrm{CD} 93^{+}$ $\mathrm{CD} 45 \mathrm{R}^{+} \mathrm{CD} 19^{+}$pro-/pre-B cells with retroviruses encoding either GFP or Bmi-1. Ectopic expression of Bmi-1 in old pro/pre-B cells restores their growth potential compared with their GFP transduced counterparts. $P$ values are based on comparisons between each population and the young GFP transduced cells. $\left({ }^{*}\right) P<0.01$; ${ }^{\star \star *} \mid P<0.0002$. $(B)$ Expression of Bmi-1, p16 ${ }^{\text {Ink4a }}$, and Arf relative to $\beta$-Actin in young and old pro-/pre-B cells $13 \mathrm{~d}$ following transduction with retroviruses encoding either Bmi-1 or GFP. Values are normalized to expression of each gene in the GFP transduced old pro-/pre-B cells. $P$ values are based on comparison of the expression in each population relative to the expression in old $\mathrm{GFP}^{+}$cells. $\left.{ }^{*}\right) P<0.04$; (\#) $P<0.0008$. $(C)$ The frequency of proliferating Ki67 $7^{+}$ cells is elevated in cultures established with old Bmi-1 transduced pro-/pre-B cells as compared with old GFP transduced pro-/pre-B cells. $(D)$ Ectopic expression of Bmi-1 (right panel) decreases the frequency of AnnexinV $\mathrm{V}^{+}$cells in old pro-/pre-B cells to levels comparable with their GFP transduced young counterparts (left panel). (E) Bmi-1 transduced young (top) and old (bottom) pro-/pre-B cells can differentiate into IgM ${ }^{+}$ cells in vitro.

the deletion of $\mathrm{p} 16^{\text {Ink4a }}$ and Arf in B lineage cells where they are highly expressed would be greatly advantageous to tumor development. Taken together, these observations suggest that the extent and mechanisms of aging within specific hematopoietic lineages are distinct and dictate the incidence, development, and etiology of different types of leukemia.

Our data showing that levels of $\mathrm{p} 16^{\mathrm{Ink} 4 \mathrm{a}}$ and Arf expression increase with age in the B lineage also provide a mechanistic explanation for the clinical observation that the frequency of lymphoid leukemias declines with age and that leukemias in adults more frequently involve the myeloid compartment (Rossi et al. 2008). However, while the preferential expression of $\mathrm{p} 16^{\text {Ink4a }}$ and Arf in aged lymphoid progenitors enhances resistance to malignant transformation, this comes at the expense of their growth and survival potential. Our data indicate that age-associated proliferative defects in B lineage progenitors can be reversed by suppressing $\mathrm{p} 16^{\text {Ink } 4 a}$ and Arf expression, suggesting that they are potential therapeutic targets for rejuvenating the aged immune system. Although suppression of $\mathrm{p} 16^{\text {Ink4a }}$ and Arf increases susceptibility to malignant transformation, there may be situations where that risk becomes an acceptable tradeoff for improved immune function.

\section{Materials and methods}

Mice

Four-week-old C57BL/6J (B6) and B6.129S7-Ragltm1Mom/J (Rag1-/-) mice were purchased from The Jackson Laboratory. Seventeen-monthold to 20-mo-old B6 mice were purchased from the National Institute on Aging colony. Animals were housed in the Division of Laboratory Animal Medicine, and experiments were conducted according to UCLA Institutional Animal Care and Use Committee guidelines.

\section{Cell sorting}

BM progenitors were sorted on a FACSaria (Becton Dickenson) following immunostaining according to the phenotypes in Figure 1A-F. Lineage depletion antibody cocktails used for each population are as described (Signer et al. 2007b). Purified cells were analyzed for p16 ${ }^{\text {Ink4a }}$, Arf, Bmi-1, Ets1, and Id1 expression by qPCR or used for retroviral transduction.

\section{$q P C R$}

Gene expression in isolated uncultured BM populations or retrovirally transduced cultured cells was performed by qPCR. RNA was extracted with the RNeasy Plus micro- or minikit (Qiagen), and cDNA was synthesized with $\mathrm{RT}^{2}$ First Strand kit (SuperArray). Reactions were run in $25 \mu \mathrm{L}$ volumes with SYBR green qPCR master mix (Biorad) as recommended by the manufacturer. Presence of single PCR products was confirmed by melt curve analysis. Data were analyzed with Biorad IQ5 software using the Pfaffl method with $\beta$-Actin or GAPDH as the reference gene. Amplification efficiencies were routinely found to be between 95\% and $105 \%$. All reactions were run twice in duplicate. As reported in other studies (Zindy et al. 1997; Krishnamurthy et al. 2004; Molofsky et al. 2006), the limited number of hematopoietic progenitors that could be obtained, the low expression levels of $\mathrm{p} 16^{\text {Ink4a }}$ and Arf, and limited antibody sensitivity precluded quantification of protein levels. p16 $16^{\text {Ink4a }}$ primer sequences were as follows: GTGTGCATGACGTGCGGG (forward) and GCAGTTCGAATCTGCACCGTAG (reverse). Arf primer sequences were as follows: GCTCTGGCTTTCGTGAACATG (forward) and TCGAATCTGCACCGTAGTTGAG (reverse). RT $^{2}$ Primer sets for Bmi-1, Ets1, Id1, $\beta$-Actin, and GAPDH were all purchased from SuperArray.

Retroviral transduction and culture of pro-/pre-B cells

Pro-/pre-B cells were transduced in a modified progenitor cell culture system optimized for B lineage cells (Montecino-Rodriguez and Dorshkind 2006; Signer et al. 2007b). Purified cells $\left(10^{5}-10^{6}\right)$ were seeded in six-well plates in complete media (Supplemental Material). Confluent S17 stromal layers grown in 0.4- $\mu \mathrm{m}$ transwell inserts (Becton Dickinson) were fitted into each well. Retrovirus supernatant was added to the bottom well four times over a 24-h period, except for leukemia studies (Supplemental Material).

For p16 $6^{\text {Ink4a }}$ and Arf experiments, transduced cells were grown for an additional 24 or 96 h. For Bmi-1 experiments, cells were grown for $96 \mathrm{~h}$ and resorted based on GFP expression. $\mathrm{GFP}^{+}\left(\mathrm{Bmi}^{-} 1^{+}\right.$or $\mathrm{GFP}^{+}$controls) cells were then reseeded in the modified progenitor cell culture system for 10-15 d. Cells produced in these cultures were counted, tested for GFP and B lineage cell antigen expression, gene expression, cell cycle status, or differentiation potential (Supplemental Material). The intensity of GFP was monitored in all populations following transduction and was equivalent.

\section{Statistical analysis}

Unless indicated otherwise, data are expressed as a mean \pm SEM. Differences between groups were tested by a two-tailed, unpaired Student's $t$ test $(\alpha=0.05)$.

\section{Acknowledgments}

We thank C. Sherr, M. Roussel, S. Lowe, F. Zaera, R. Lukacs D. Lawson, and J. McLaughlin for reagents and/or advice. This work was supported by a grant from the National Institutes of Health (NIH) (AG-21450). O.N.W is an investigator of the Howard Hughes Medical Institute. R.A.J.S. is supported by a fellowship from the California Institute for Regenerative Medicine (TI-00005). The UCLA Flow Cytometry Core Facility is supported by NIH grants CA-16042 and AI-28697. 
A

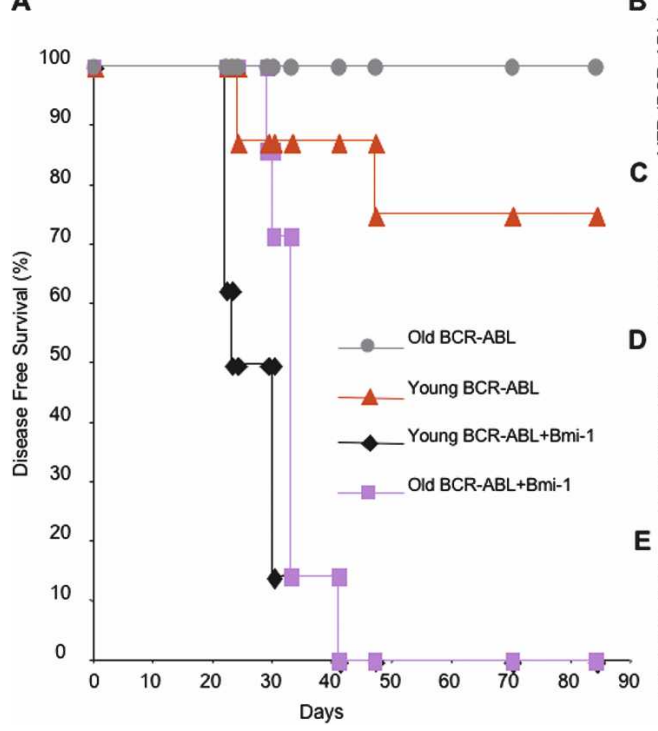

B

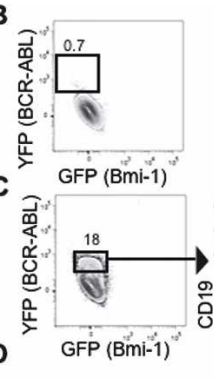

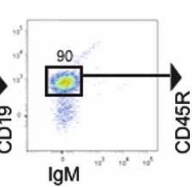
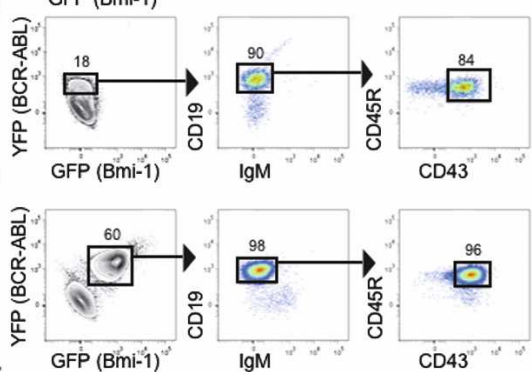

E

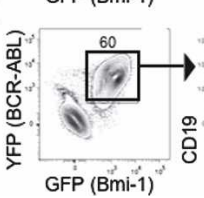

IgM

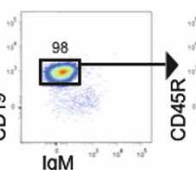

$\lg M$

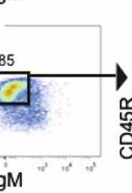

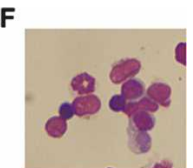

G

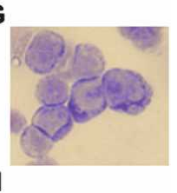

H



I

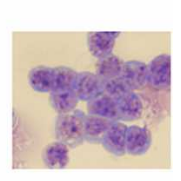

Figure 5. Ectopic expression of Bmi-1 makes old B lineage cells susceptible to leukemic transformation by BCR-ABL. (A) Pro-/pre-B cells from young and old mice were simultaneously cotransduced with BCR-ABL and Bmi-1 or with BCR-ABL alone and were transplanted into Rag $1^{-/-}$ mice. Mice were sacrificed when they showed symptoms of disease. BCR-ABL transduced old cells did not generate leukemia while $100 \%$ of recipients repopulated with BCR-ABL and Bmi-1 cotransduced cells developed disease by day 41 post-transplantation. $(B-E)$ Representative

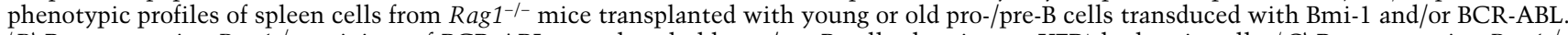

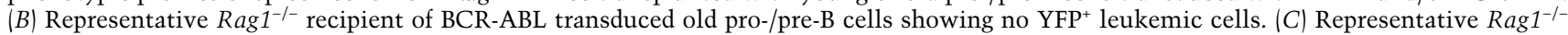
recipient of BCR-ABL transduced young pro-/pre-B cells showing abundant $\mathrm{YFP}^{+}$leukemic cells with a CD45R ${ }^{+} \mathrm{CD}_{19}{ }^{+} \mathrm{IgM}^{-} \mathrm{CD} 43^{+}$pro-B-cell phenotype. Representative Rag1 $1^{-/}$recipients of young $(D)$ and old $(E)$ pro-/pre-B cells cotransduced with BCR-ABL and Bmi-1 showing abundant $\mathrm{GFP}^{+} \mathrm{YFP}^{+}$leukemic cells with a CD45R ${ }^{+} \mathrm{CD} 19^{+} \mathrm{IgM}^{-} \mathrm{CD} 43^{+}$pro-B-cell phenotype. $(F-I)$ Photomicrographs of spleen cell cytospins from $(F)$ a


duced young $(G)$, Bmi-1 and BCR-ABL cotransduced young $(H)$ and old $(I)$ pro-/pre-B cells showing abundant lymphoid blasts. Images in $F-I$ were viewed at 500× magnification with a Leitz Laborlux D microscope using a FLUOTAR 50×/0.70 NA phase-contrast objective.

\section{References}

Akashi, K., Traver, D., Miyamoto, T., and Weissman, I.L. 2000. A clonogenic common myeloid progenitor that gives rise to all myeloid lineages. Nature 404: 193-197.

Baker, D.J., Perez-Terzic, C., Jin, F., Pitel, K., Niederlander, N.J., Jeganathan, K., Yamada, S., Reyes, S., Rowe, L., Hiddinga, H.J., et al. 2008. Opposing roles for p16 Ink4a and p19 Arf in senescence and ageing caused by BubR1 insufficiency. Nat. Cell Biol. 10: 825-836.

Hardy, R.R., Carmack, C.E., Shinton, S.A., Kemp, J.D., and Hayakawa, K. 1991. Resolution and characterization of pro-B and pre-pro-B cell stages in normal mouse bone marrow. J. Exp. Med. 173: 1213-1225.

Jacobs, J.J., Kieboom, K., Marino, S., DePinho, R.A., and van Lohuizen, M. 1999. The oncogene and Polycomb-group gene bmi-1 regulates cell proliferation and senescence through the ink4a locus. Nature 397: 164-168.

Janzen, V., Forkert, R., Fleming, H.E., Saito, Y., Waring, M.T., Dombkowski, D.M., Cheng, T., DePinho, R.A., Sharpless, N.E., and Scadden, D.T. 2006. Stem-cell ageing modified by the cyclin-dependent kinase inhibitor p16INK4a. Nature 443: 421-426.

Kamijo, T., Zindy, F., Roussel, M.F., Quelle, D.E., Downing, J.R., Ashmun, R.A., Grosveld, G., and Sherr, C.J. 1997. Tumor suppression at the mouse INK4a locus mediated by the alternative reading frame product p19ARF. Cell 91: 649-659.

Kim, W.Y. and Sharpless, N.E. 2006. The regulation of INK4/ARF in cancer and aging. Cell 127: 265-275.

Kondo, M., Weissman, I.L., and Akashi, K. 1997. Identification of clonogenic common lymphoid progenitors in mouse bone marrow. Cell 91: 661-672.

Krishnamurthy, J., Torrice, C., Ramsey, M.R., Kovalev, G.I., Al-Regaiey, K., Su, L., and Sharpless, N.E. 2004. Ink4a/Arf expression is a biomarker of aging. J. Clin. Invest. 114: 1299-1307.

Krishnamurthy, J., Ramsey, M.R., Ligon, K.L., Torrice, C., Koh, A., Bonner-Weir, S., and Sharpless, N.E. 2006. p16INK4a induces an agedependent decline in islet regenerative potential. Nature 443: 453457.
Matheu, A., Pantoja, C., Efeyan, A., Criado, L.M., Martin-Caballero, J., Flores, J.M., Klatt, P., and Serrano, M. 2004. Increased gene dosage of Ink4a/Arf results in cancer resistance and normal aging. Genes \& Dev. 18: 2736-2746.

Miller, J.P. and Allman, D. 2003. The decline in B lymphopoiesis in aged mice reflects loss of very early B-lineage precursors. I. Immunol. 171: 2326-2330.

Min, H., Montecino-Rodriguez, E., and Dorshkind, K. 2005. Effects of aging on early B- and T-cell development. Immunol. Rev. 205: 7-17.

Min, H., Montecino-Rodriguez, E., and Dorshkind, K. 2006. Effects of aging on the common lymphoid progenitor to pro-B cell transition. $J$. Immunol. 176: 1007-1012.

Molofsky, A.V., Slutsky, S.G., Joseph, N.M., He, S., Pardal, R., Krishnamurthy, J., Sharpless, N.E., and Morrison, S.J. 2006. Increasing p16INK4a expression decreases forebrain progenitors and neurogenesis during ageing. Nature 443: 448-452.

Montecino-Rodriguez, E. and Dorshkind, K. 2006. Stromal cell-dependent growth of B-1 B cell progenitors in the absence of direct contact. Nat. Protocols 1: 1140-1144.

Mullighan, C.G., Williams, R.T., Downing, J.R., and Sherr, C.J. 2008. Failure of CDKN2A/B (INK4A/B-ARF)-mediated tumor suppression and resistance to targeted therapy in acute lymphoblastic leukemia induced by BCR-ABL. Genes \& Dev. 22: 1411-1415.

Nielsen, G.P., Stemmer-Rachamimov, A.O., Shaw, J., Roy, J.E., Koh, J., and Louis, D.N. 1999. Immunohistochemical survey of p16INK4A expression in normal human adult and infant tissues. Lab. Invest. 79: 1137-1143.

Ohtani, N., Zebedee, Z., Huot, T.J., Stinson, J.A., Sugimoto, M., Ohashi, Y., Sharrocks, A.D., Peters, G., and Hara, E. 2001. Opposing effects of Ets and Id proteins on p16INK4a expression during cellular senescence. Nature 409: 1067-1070.

Park, I.K., Qian, D., Kiel, M., Becker, M.W., Pihalja, M., Weissman, I.L., Morrison, S.J., and Clarke, M.F. 2003. Bmi-1 is required for maintenance of adult self-renewing haematopoietic stem cells. Nature 423: 302-305.

Rossi, D.J., Bryder, D., Zahn, J.M., Ahlenius, H., Sonu, R., Wagers, A.J., 
and Weissman, I.L. 2005. Cell intrinsic alterations underlie hematopoietic stem cell aging. Proc. Natl. Acad. Sci. 102: 9194-9199.

Rossi, D.J., Jamieson, C.H., and Weissman, I.L. 2008. Stems cells and the pathways to aging and cancer. Cell 132: 681-696.

Sachs, Z., Sharpless, N.E., DePinho, R.A., and Rosenberg, N. 2004 p16(Ink4a) interferes with Abelson virus transformation by enhancing apoptosis. J. Virol. 78: 3304-3311.

Serrano, M., Lee, H., Chin, L., Cordon-Cardo, C., Beach, D., and DePinho, R.A. 1996. Role of the INK4a locus in tumor suppression and cell mortality. Cell 85: 27-37.

Serrano, M., Lin, A.W., McCurrach, M.E., Beach, D., and Lowe, S.W. 1997. Oncogenic ras provokes premature cell senescence associated with accumulation of p53 and p16INK4a. Cell 88: 593-602.

Sharpless, N.E. and DePinho, R.A. 2007. How stem cells age and why this makes us grow old. Nat. Rev. Mol. Cell Biol. 8: 703-713.

Sharpless, N.E., Bardeesy, N., Lee, K.H., Carrasco, D., Castrillon, D.H., Aguirre, A.J., Wu, E.A., Horner, J.W., and DePinho, R.A. 2001. Loss of p16Ink4a with retention of p19Arf predisposes mice to tumorigenesis. Nature 413: 86-91.

Sherr, C.J. 2001. The INK4a/ARF network in tumour suppression. Nat. Rev. Mol. Cell Biol. 2: 731-737.

Sherr, C.J. and McCormick, F. 2002. The RB and p53 pathways in cancer. Cancer Cell 2: 103-112.

Signer, R.A., Montecino-Rodriguez, E., and Dorshkind, K. 2007a. Aging, B lymphopoiesis, and patterns of leukemogenesis. Exp. Gerontol. 42: 391-395.

Signer, R.A., Montecino-Rodriguez, E., Witte, O.N., McLaughlin, J., and Dorshkind, K. 2007b. Age-related defects in B lymphopoiesis underlie the myeloid dominance of adult leukemia. Blood 110: 1831-1839.

Spangrude, G.J., Heimfeld, S., and Weissman, I.L. 1988. Purification and characterization of mouse hematopoietic stem cells. Science 241: 5862.

Stephan, R.P., Sanders, V.M., and Witte, P.L. 1996. Stage-specific alterations in murine B lymphopoiesis with age. Int. Immunol. 8: 509518.

Van der Put, E., Frasca, D., King, A.M., Blomberg, B.B., and Riley, R.L. 2004. Decreased E47 in senescent B cell precursors is stage specific and regulated posttranslationally by protein turnover. J. Immunol. 173: $818-827$.

Williams, R.T., Roussel, M.F., and Sherr, C.J. 2006. Arf gene loss enhances oncogenicity and limits imatinib response in mouse models of Bcr-Abl-induced acute lymphoblastic leukemia. Proc. Natl. Acad. Sci. 103: 6688-6693.

Wong, S. and Witte, O.N. 2004. The BCR-ABL story: Bench to bedside and back. Annu. Rev. Immunol. 22: 247-306.

Yilmaz, O.H., Kiel, M.J., and Morrison, S.J. 2006. SLAM family markers are conserved among hematopoietic stem cells from old and reconstituted mice and markedly increase their purity. Blood 107: 924 930.

Zindy, F., Quelle, D.E., Roussel, M.F., and Sherr, C.J. 1997. Expression of the p16INK4a tumor suppressor versus other INK4 family members during mouse development and aging. Oncogene 15: 203-211. 


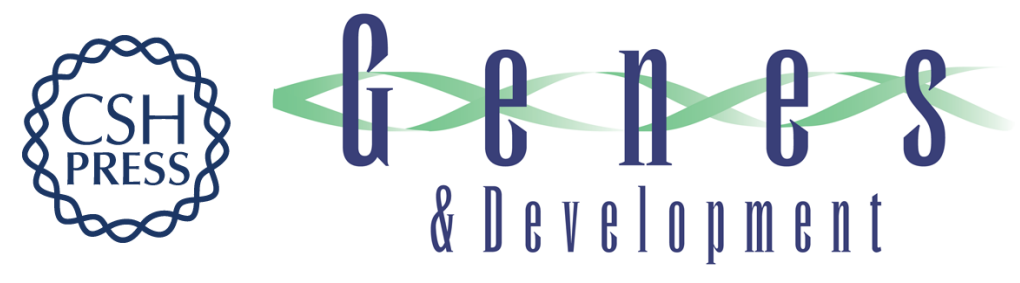

\section{Aging and cancer resistance, in lymphoid progenitors are linked processes conferred by $\mathrm{p} 16$ Ink4a and Arf}

Robert A.J. Signer, Encarnacion Montecino-Rodriguez, Owen N. Witte, et al.

Genes Dev. 2008, 22:

Access the most recent version at doi:10.1101/gad.1715808

Supplemental http://genesdev.cshlp.org/content/suppl/2008/11/24/22.22.3115.DC1
Material

References This article cites 38 articles, 12 of which can be accessed free at:

http://genesdev.cshlp.org/content/22/22/3115.full.html\#ref-list-1

License

Email Alerting

Receive free email alerts when new articles cite this article - sign up in the box at the top

Service

right corner of the article or click here.

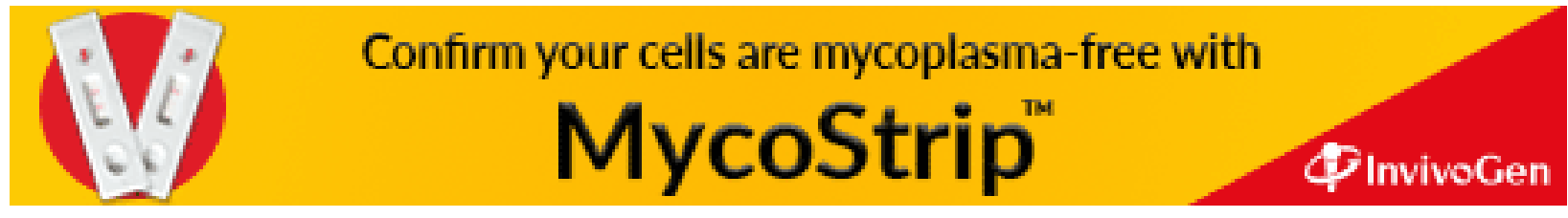

